\title{
ПРАВООХРАНИТЕЛЬНЫЕ ОРГАНЫ ВОСТОЧНОЙ СИБИРИ В АРХИВНЫХ ИСТОЧНИКАХ (ДОРЕВОЛЮЦИОННЫЙ ПЕРИОД)
}

Статья посвящена изучению источников по истории органов власти Восточной Сибири. Исследуется уровень освещенности деятельности правоохранительных структур по вопросам системы их устройства, полномочий, компетенции. Изучается источниковая база по рассмотрению специфики взаимодействия между уровнями власти дореволюционной России. В основе исследования лежат материалы нового путеводителя Государственного архива Иркутской области по дореволюционным фондам.

Ключевые слова: правоохранительные органы, Сибирь, архив, исторический источник.

\section{LAW-ENFORCEMENT AGENCIES OF THE EASTERN SIBERIA IN ARCHIVAL SOURCES (PRE-REVOLUTIONARY PERIOD)}

The article deals with the studying of sources on history of lawenforcement agencies in the Eastern Siberia. In addition, the article studies the level of coverage of law-enforcement agencies' activity on problems of its organization system, powers, competence. The sources' base on specifics of cooperation between the levels of powers in the pre-revolutionary Russia is studied. The basis of the research is the materials of new guidebook of the State Archives of Irkutsk region on pre-revolutionary funds.

Keywords: law-enforcement agencies, Siberia, archive, historical source.

В вопросах обеспечения государственной безопасности в современных условиях роль правоохранительных органов страны сложно переоценить. Поэтому таким важным является изучение истории их становления, т.е. дореволюционный этап развития. Опыт фрормирования структуры органов, алгоритма работы, способов взаимодействия между всеми элементами системы является ценнейшим на современном этапе реформирования государственного аппарата. В обстоятельном, скрупулезном изучении этих вопросов существенный вклад вносят документы архивохранилищ. Одним из таких является Государственный архив Иркутской области. 
Фонды Государственного архива Иркутской (ГАИО) области всегда являлись важнейшим источником в деле изучения истории Восточной Сибири. Государственный архив Иркутской области - один из крупнейших региональных архивов России, здесь сосредоточено 2600 фондов и более 1 млн единиц хранения [4, с. 733].

Ведь именно в ГАИО сосредоточены особо ценные материалы по истории Восточносибирского генерал-губернаторства с подчинением ему Енисейской губернии, Забайкальской и Якутской областей за почти столетнюю историю (с 1822 по 1917 г.). В 2018 г. вышел в свет новый путеводитель ГАИО [8]. Значение путеводителя, как справочного издания для исследователей во все времена сложно переоценить. Уже в XVIII-XIX вв. значение путеводителя как краткого, но информативного и необходимого обществу сборника было определено. Конечно, целевое назначение справочников, касающихся географических пунктов, туристических маршрутов, учреждений культуры отличается от научных сборников, созданных для исследования материалов, накопленных в библиотеках, архивах страны. И все же, при этом, язык и структура научного путеводителя должны быть одинаково удобными, понятными для широкого круга читателей: как профессиональных исследователей, так и интересующихся обывателей. Путеводитель - важнейшая составляющая единой системы научно-справочного аппарата государственного архива, вот почему его издание - событие долгожданное, как среди историков, так и профессиональных архивных работников. С момента выхода в свет последнего выпуска путеводителя прошло более 30 лет, понятно, что часть сведений того издания устарела, с определенного количества дел был снят гриф «Секретно» и они стали более доступны для исследователя.

Значимой особенностью современного издания является наличие обстоятельных исторических справок к каждому из описанных фондов хранилища, что является необходимой составляющей в деле изучения особенностей структуры, деятельности, соподчиненности правоохранительных органов власти.

Наиболее значимыми для исследователей отечественных правоохранительных органов являются фонды органов власти и управления. Это, прежде всего, фронд Главного управления Восточной Сибири (ф. 24), Канцелярии Иркутского генерал-губернатора (ф. 25) и Иркутского губернского управления (ф. 32). Эти фонды содержат самые разнообразные виды документальных источников, включающих в себя информацию о деятельности всех ведомств Восточной Сибири. Так, фонд 24 содержит сведения о ревизии всех местных учреждений, назначение и снятие с должностей всех чиновников на местах, ежегодные отчеты по губернскому управлению. Описи фронда содержат сведения о строительстве, обеспечении тюрем, переписку о количестве пребывающих в регион преступниках, документы об учреждении в Приморской области окружных органов суда 
и прокурорского надзора (1882-1884 гг.) [8, с. 24]. Материалы фронда отличаются большим разнообразием видов документов, их информационной насыщенностью, так как содержат подробные сведения о деятельности всех органов власти Восточной Сибири. В том числе и об устройстве полицейских частей в крае, тюрем в генерал-губернаторстве.

Фонд 25 содержит важную информацию, раскрывающую особенности механизма работы правоохранительных ведомств в условиях массовой ссылки в край преступного элемента. Значительную часть описей занимают статейные и алфавитные списки государственных преступников, сведения о лицах, состоящих под гласным надзором полиции. Важный пласт работы канцелярии генерал-губернатора состоял в рассмотрении различных жалоб и прошений ссыльных, в том числе касавшихся выдачи им разрешений о выезде из уезда, к которому они были приписаны в целях заработка [1, л. 1].

Кроме того, фонд содержит сведения о служащих в сибирских учреждениях чиновниках. Эта информация становится предметом специального исследования только в последние десятилетия. Ценные данные содержатся в отчетах о деятельности местного тюремного ведомства, так как подробно освещают все стороны организации работы ведомства. В делах также имеется, например, подаренный Иркутскому генерал-губернатору А.И. Пантелееву в 1900 г. отчет о деятельности Главного тюремного управления, который являлся практически пошаговым руководством к действию местного тюремного ведомства [2, л. 1].

Фонд 32 Иркутского губернского управления содержит 27020 единиц хранения. В его материалах также есть общая статистическая часть: всеподданнейшие отчеты и сведения о состоянии губернии, в том числе сведения о борьбе правоохранительного блока с революционной пропагандой, донесения полиции о наблюдении за ссыльными. В документах зафиксированы также предписания и отчеты о текущем ремонте мест заключения, уровне жалования тюремных чиновников, данные о постройке Иркутского тюремного замка (1858 г.) [8, с. 74]. Фонд содержит многочисленные рапорты начальников тюрем о состоянии зданий, об особенностях их содержания и о затраченных на это средствах. Особое значение, как для центральных властей, так и для губернских, имели сведения о неблагонадежных лицах, состоящих под надзором полиции. Изданный путеводитель в описании фондов уделяет больше чем предшествующие издания советского периода внимания подробному указанию всех видов документов в описях, всесторонне отражающих деятельность ведомств.

Важное место в новом путеводителе отводится деятельности каждого ведомства, осуществлявшего охрану государственного строя. В том числе это касается и работы Иркутского губернского прокурора (ф. 239), Прокурора Иркутской судебной палаты (ф. 245), Прокурора 
Иркутского окружного суда (ф. 242). Также в новом справочном издании уделено внимание деятельности следственных комиссий по особо важным (революционным) делам. Отрадно, что в исторических справках к фондам государственных органов отмечена и конкретная подведомственность органов Прокуратуры на каждом этапе реформирования. Поэтому в путеводителе соблюдается не только хронологический принцип, но и принцип расположения материалов фондов с учетом соблюдения иерархии и соподчиненности государственных структур. В отличие от путеводителей по ГАИО предыдущего периода [3, с. 37], в новом уделено внимание работы ведомств не только с политическими, но и уголовными преступниками. Имеются также циркуляры и предписания по вопросам судопроизводства, вертикального и горизонтального уровней подчиненности и взаимодействия государственных структур. Отмечено также наличие сведений о надзоре не только за ходом ведения следствия, но и за местами заключения, целевыми тратами государственных денежных средств как на осужденных, так и на сотрудников ведомств. В делах также имеются сведения о представленных к государственным наградам чиновников, а также списков награждаемых присяжных заседателей. Тем самым видно, насколько всесторонне возможно изучение правоохранительных органов благодаря такому обширному и разнообразному по видам документов пласту архивных источников.

В документах ГАИО среди правоохранительных органов важная роль отмечена и в деятельности нотариальных органов: фр. 447 Иркутского городового маклера, ф. 418 Иркутского публичного нотариуса раскрывает деятельность данного правоохранительного ведомства.

Помимо полицейских управлений отмечена деятельность таможенных органов (ф. 153). Дана подробная, обстоятельная историческая справка о времени создания Иркутской таможни, структурных изменениях, влияющих на функционал государственного органа. Подробное изложение содержания ф. 153 отражает значение деятельности фрискальной дореволюционной структуры в деле пополнения казны страны пошлинами, недопущения контрабанды для развития законной торговли в Сибири.

Значимая роль в путеводителе отведена публикации данных о документах по пенитенциарным учреждениям Сибири. Фонд $34-$ Иркутская губернская тюремная инспекция. Этот обширный фонд, содержащий 43199 единиц хранения, содержит уникальные документы о полномочиях Иркутского губернского тюремного инспектора, уездных инспекторов, требования к ведению делопроизводства, статистические сведения о заключенных, прошения ссыльнокаторжных, в том числе о замене мест причисления ссыльнопоселенцев. Как в современных, так и дореволюционных правоохранительных органах уделяется большое внимание порядку ведения отчетности по тюремному делопроизводству [5, с. 120]. Поэтому в материалах архива отложились приказы, распо- 
ряжения о фрормировании отчетности ведомства. В материалах фронда также имеются сведения о хозяйственной деятельности тюрем, о медицинском обслуживании персонала, что является ценной информацией в деле изучения особенностей службы чиновников. Также часть документов посвящено деятельности Иркутского детского приюта, что может способствовать дальнейшему изучению данных тем [6, с. 185].

Фонд 600 Иркутского губернского жандармского управления (18671917 гг.), несмотря на относительно небольшое количество дел (1312), тем не менее, очень содержателен, информативен. Управление было организовано на основании «Положения о корпусе жандармов от 19 сентября 1867 г.» [8, с. 207]. В многочисленных распоряжениях, инструкциях, циркулярах содержится разнообразный материал об организации полицейского надзора за политическими осужденными, о происшествиях по Иркутской губернии. Фонд включает в себя уставы, списки, переписку о деятельности отделений политических партий. Содержит также сведения о количестве занятых на работах политических ссыльных, их прошения, межведомственную переписку об образе жизни этих преступников.

Фонд 603 Жандармского полицейского управления Забайкальской железной дороги, хотя и является небольшим по числу дел (447 единиц хранения), однако, включает в себя ценные документы: постановления Иркутского генерал-губернатора, а также приказы начальника штаба Отдельного корпуса жандармов, командующего Сибирским военным округом, дела о производстве дознаний по политическим преступлениям. Фонд 602 Иркутского отделения жандармского полицейского управления Забайкальской железной дороги, содержит ценные сведения о политической благонадежности работников Забайкальской железной дороги. Материалы о волнениях рабочих и беспорядках на железной дороге являются важным источником в деле изучения способов защиты государственного строя правоохранительными органами. Фонд 601 Иркутского районного охранного отделения содержит 217 дел. По материалам фонда можно исследовать сведения должностных лиц о политически неблагонадежных преступниках, фотографии задержанных, а также изучить особенности агентурной работы и формы отчетности сотрудников ведомства.

Важные сведения о формировании судебной органов Восточной Сибири содержатся в фондах 7, 240, 241, 243, 245, 246, 524, 723, 783 сформировали материалы о деятельности окружных судов и Иркутской судебной палаты [7, с. 59]. В материалах фронда 246 содержатся не только журналы судебных заседаний, но и отчеты о деятельности государственного органа, переписка об уклонении свидетелей, отражена также деятельность личного состава членов суда. В путеводителе по ГАИО советского периода в силу понятных идеологических причин не уделялось внимание освещению вопросов особенностей самой службы в государственном аппарате. В новом путеводителе отмечено наличие 
дел, посвященных составу семей чиновников, уровню их благосостояния, списки награждаемых за особое усердие в службе.

Таким образом, как видно из приведенных материалов, фонды ГАИО обладают разнообразными, информативно насыщенными видами источников, способствующими всестороннему изучению деятельности правоохранительных органов. Документы позволят глубже изучить особенности устройства самой службы, ротацию кадров, систему поощрений и дисциплинарных взысканий с сотрудников, факты законного и нецелевого использования бюджетных средств и другие вопросы.

\section{Список использованной литературы и источников}

1. Государственный архив Иркутской области (ГАИО). - Ф. 25. - Оп. 6. Д. 677 a.

2. ГАИО. - Ф. 25. - Оп. 6. - Д. 1104.

3. Государственный архив Иркутской области. Путеводитель / сост. : Н. И. Баранова, Н. И. Быкова, З. Д. Гусева, Р. Ф. Мухамедзянов, Т. В. Чарушина. - Иркутск : Вост.-Сиб. кн. изд-во, 1975. - 293 с.

4. Иванов А. А. Из истории научно-издательской деятельности Государственного архива Иркутской области / А. А. Иванов, Е. В. Ильина // Вестник архивиста. - 2018. - № 3. - С. 731-739.

5. Курас С. Л. Делопроизводство в правоохранительной системе дореволюционной России / С. Л. Курас // Власть. - 2011. — № 8. - С. 119-121.

6. Курас С. Л. Система организации исправительных учреждений для несовершеннолетних в дореволюционной России / С. Л. Курас // Власть. — 2015. № 1. - С. 185-189.

7. Курас Т. Л. Кадровая политика самодержавия в судебных палатах Российской империи / Т. Л. Курас // Гуманитарный вектор. — 2011. — № 3 (27). — С. 57-61.

8. Путеводитель по фондам Государственного архива Иркутской области : в 2 ч. Ч. 1: Досоветский период / сост. : Ю. П. Колмаков, Е. А. Луговская, Н. В. Чичкова (отв. сост.), И. А. Чукавин, Н. В. Шашкова. - Иркутск : Изд-во «Оттиск», 2017. — 548 с.

\section{Информация об авторах}

Курас Софья Леонидовна - кандидат исторических наук, доцент кафедры таможенного дела и правоведения, Иркутский государственный университет путей сообщения, 664074, г. Иркутск, ул. Чернышевского, 15; e-mail: kuras@list.ru

Марченко Светлана Сергеевна - старший преподаватель кафедры таможенного дела и правоведения, Иркутский государственный университет путей сообщения, 664074, г. Иркутск, ул. Чернышевского, 15; e-mail: s.s.marchenko@mail.ru

\section{Authors}

Sofia L. Kuras - PhD in History, Associate Professor Customs Affairs and Jurisprudence, Irkutsk State Transport University, 15 Chernyshevsky St., 664074, Irkutsk, Russia; e-mail: kuras@list.ru

Svetlana S. Marchenko - Senior Lecturer Customs Affairs and Jurisprudence, Irkutsk State Transport University, 15 Chernyshevsky St., 664074, Irkutsk, Russia; e-mail: s.s.marchenko@mail.ru 